\title{
NOTES
}

\section{F390B and C, New Antitumor Dihydroxanthone Derivatives Isolated from Penicillium sp.}

\author{
Seirchi Sato, Ryusuke Nakagawa, \\ Ryosuke Fudo, Yumiko FuKuda, \\ Toshiniko Yoshimura, Ken-ICHI Kaida, \\ Toshiniko ANDo, TOSHIYUKi KameYama \\ and TAKASHI TSUII*
}

Central Research Laboratories, Ajinomoto Co., Inc., 1-1 Suzuki-cho, Kawasaki 210, Japan

(Received for publication March 27, 1997)

In our search for new antitumor substances, cytotoxic dihydroxanthone derivatives, F390 (3) and F390B (1) were isolated from the mycelium extract of Penicillium sp. AJ117292, and F390C (2) was isolated from Penicillium sp. AJ117291, respectively. F390 was identical to the known compound, nidulalin $\mathrm{A}^{1,2)}$ (Structures shown in Fig. 1). In this communication, we describe fermentation, isolation, structure elucidation and antitumor activities of F390B, C and nidulalin A.

Culture, AJ117292, was isolated from a soil sample collected at Kanagawa Prefecture, Japan and the fungus, AJ117291 was isolated from a soil sample collected at Ehime Prefecture, Japan. Both of the strains were identified as Penicillium sp. by morphological characteristics, and AJ117292 was deposited at the National Institute of Bioscience and Human-Technology, Ibaraki Prefecture, Japan with accession number FERM P14419. The production media used for the cultivation of AJ117292 and AJ117291 were medium $\mathrm{M}$ and medium $\mathrm{P}$, respectively. Medium M contained malt extract (Difco) $20 \mathrm{~g}$, oatmeal powder $10 \mathrm{~g}$, peptone (Difco) $5 \mathrm{~g}$, glucose $10 \mathrm{~g}$, soluble starch $10 \mathrm{~g}$ in distilled water (1 liter), $\mathrm{pH}$ 6.0. Medium $\mathrm{P}$ contained bact potato dextrose broth (Difco) $24 \mathrm{~g}$ in distilled water (1 liter), $\mathrm{pH}$ 6.0. Both strains were cultivated at $25^{\circ} \mathrm{C}$ for 4 days in a $500-\mathrm{ml}$ Erlenmeyer flasks containing $100 \mathrm{ml}$ of production media on a rotary shaker $(180 \mathrm{rpm})$.

The culture broth of Penicillium sp. AJ117292 (1 liter) was centrifuged at $4000 \mathrm{rpm}$ for 20 minutes to obtain mycelium, which was extracted with acetone (2 liters). The extract was concentrated in vacuo to an aqueous suspension, which was extracted with EtOAc $(400 \mathrm{ml} \times$ 2). The organic layer was dried in vacuo. The residue was applied to a silica gel column (5 i.d. $\times 37 \mathrm{~cm}$, Kieselgel $60 \mathrm{Merck}$ ), and eluted with $\mathrm{CHCl}_{3}$ and $\mathrm{CHCl}_{3}$ - EtOAc $(95: 5)$. Two active fractions were obtained. The fraction eluted with $\mathrm{CHCl}_{3}$ - EtOAc $(95: 5)$ was subjected to a silica gel column ( 3 i.d. $\times 40 \mathrm{~cm}$ ), and eluted with $\mathrm{CHCl}_{3}$ EtOAc $(98: 2)$. The active fraction was chromatographed on Sephadex LH-20 column $(2.5$ i.d. $\times 40 \mathrm{~cm})$ with $\mathrm{CHCl}_{3}-\mathrm{MeOH}(1: 1)$ followed by crystallization from $n$-hexane-ether to give F390 (3, $600 \mathrm{mg})$. Purification of the other fraction eluted with $\mathrm{CHCl}_{3}$ was achieved on a column of reverse phase silica gel $(2$ i.d. $\times 20 \mathrm{~cm}$, Cosmosil $140 \mathrm{C}_{18}$-OPN, nacalai tesque) using aqueous $50 \%$

Fig. 1. Structures of F390 (nidulalin A, 3), B (1) and C (2).<smiles>[R]Cc1cc(O)c2c(c1)O[C@]1(C)C(=CC=C[C@H]1O)C2=O</smiles>

$\begin{array}{lll} & \mathrm{R}^{1} & \mathrm{R}^{2} \\ \text { F390B(1) } & \mathrm{Ac} & \mathrm{H} \\ \text { F390C(2) } & \mathrm{H} & \mathrm{OH} \\ \begin{array}{l}\text { F390(3) } \\ \text { (Nidulalin A) }\end{array} & \mathrm{H} & \mathrm{H}\end{array}$

Table 1. Physico-chemical properties of F390 (3), B (1), and C (2).

\begin{tabular}{|c|c|c|c|}
\hline & F390B (1) & F390C (2) & F390 (Nidulalin A) (3) \\
\hline Appearance & Yellow powder & Yellow powder & Orange needle \\
\hline $\begin{array}{l}\text { Molecular formula } \\
\text { HRFAB-MS }(m / z)\end{array}$ & $\mathrm{C}_{18} \mathrm{H}_{16} \mathrm{O}_{7}$ & $\mathrm{C}_{16} \mathrm{H}_{14} \mathrm{O}_{7}$ & $\mathrm{C}_{16} \mathrm{H}_{14} \mathrm{O}_{6}$ \\
\hline Found $(\mathrm{M}+\mathrm{H})^{+}$: & 345.0981 & 319.0810 & 303.0894 \\
\hline Calcd: & 345.0974 & 319.0818 & 303.0869 \\
\hline $\mathrm{UV} \lambda_{\max }^{\mathrm{MeOH}} \mathrm{nm}(\varepsilon)$ & $338(10500)$ & $339(8500)$ & $340(11500)$ \\
\hline Specific rotation & $-^{a}$ & $\begin{array}{l}{[\alpha]_{\mathrm{D}}^{23}=-327^{\circ}} \\
(c 0.03, \mathrm{MeOH})\end{array}$ & $\begin{array}{l}{[\alpha]_{\mathrm{D}}^{25}=-463^{\circ}} \\
\left(c 0.28, \mathrm{CHCl}_{3}\right)\end{array}$ \\
\hline
\end{tabular}

a Not measured due to limited sample quantity. 
Table 2. ${ }^{1} \mathrm{H}$ and ${ }^{13} \mathrm{C}$ NMR spectral data of F390 (3), B (1), C (2), and diacetate of F390 (4).

\begin{tabular}{|c|c|c|c|c|c|c|c|}
\hline \multirow{2}{*}{ Position } & \multirow{2}{*}{$\frac{\mathrm{F} 390 \mathrm{~B}(\mathbf{1})^{\mathrm{a}}}{{ }^{1} \mathrm{H}}$} & \multicolumn{2}{|c|}{$\mathrm{F} 390 \mathrm{C}(2)^{\mathrm{a}}$} & \multicolumn{2}{|c|}{ F390 $(3)^{\mathrm{b}}$ (Nidulalin A) } & \multicolumn{2}{|c|}{ Diacetate $(\mathbf{4})^{\mathrm{b}}$} \\
\hline & & ${ }^{1} \mathrm{H}$ & ${ }^{13} \mathrm{C}$ & ${ }^{1} \mathbf{H}$ & ${ }^{13} \mathrm{C}$ & ${ }^{1} \mathrm{H}$ & ${ }^{13} \mathrm{C}$ \\
\hline 1 & $\begin{array}{l}7.35(\mathrm{~d}) \\
J=6.8^{\mathrm{c}}\end{array}$ & $\begin{array}{l}7.38(\mathrm{dd}) \\
J=1.5,4.8\end{array}$ & 133.5 & $\begin{array}{l}7.33(\mathrm{~d}) \\
J=6.8\end{array}$ & 131.7 & $\begin{array}{l}7.23(\mathrm{~d}) \\
J=5.6\end{array}$ & 130.6 \\
\hline 2 & $6.43 \sim 6.47(\mathrm{~m})$ & $6.40 \sim 6.46^{\mathrm{d}}$ & 126.2 & $6.37 \sim 6.39^{\mathrm{d}}$ & 126.4 & $\begin{array}{l}6.40(\mathrm{dd}) \\
J=5.6,9.5\end{array}$ & 128.0 \\
\hline 3 & $6.32 \sim 6.38(\mathrm{~m})$ & $6.40 \sim 6.46^{\mathrm{d}}$ & 134.3 & $6.37 \sim 6.39^{\mathrm{d}}$ & 131.7 & $\begin{array}{l}6.28(\mathrm{dd}) \\
J=5.6,9.5\end{array}$ & 128.3 \\
\hline 4 & $\begin{array}{l}5.94(\mathrm{~d}) \\
J=5.4\end{array}$ & $\begin{array}{l}4.62(\mathrm{br} \mathrm{d}) \\
J=5.4\end{array}$ & 65.8 & $\begin{array}{l}4.67(\mathrm{~d}) \\
J=5.4\end{array}$ & 65.2 & $\begin{array}{l}5.91(\mathrm{~d}) \\
J=5.6\end{array}$ & 64.6 \\
\hline $4 a$ & & & 84.3 & & 82.9 & & 81.3 \\
\hline 5 & $6.30(\mathrm{brs})$ & $6.53(\mathrm{brs})$ & 105.8 & $6.32(\mathrm{brs})$ & 111.4 & $6.74(\mathrm{brs})$ & 116.6 \\
\hline $\begin{array}{l}6 \\
7\end{array}$ & $6.40(\mathrm{br} \mathrm{s})$ & 6.55 (brs) & $\begin{array}{l}156.1 \\
108.0\end{array}$ & $6.37 \sim 6.39^{\mathrm{d}}$ & $\begin{array}{l}151.0 \\
108.3\end{array}$ & $6.55(\mathrm{brs})$ & $\begin{array}{l}148.0 \\
118.6\end{array}$ \\
\hline 8 & & & 163.8 & & 162.8 & & 150.3 \\
\hline $8 a$ & & & 107.0 & & 105.6 & & 111.8 \\
\hline 9 & & & 184.5 & & 182.8 & & 176.5 \\
\hline $9 \mathrm{a}$ & & & 127.9 & & 127.1 & & 128.6 \\
\hline 10a & & & 159.9 & & 158.0 & & 159.7 \\
\hline 6-Me & $2.29(\mathrm{~s})$ & - & - & $2.26(\mathrm{~s})$ & 22.6 & $2.32(\mathrm{~s})$ & 21.9 \\
\hline $6-\mathrm{CH}_{2} \mathrm{OH}$ & - & 4.57 (brs) & 64.0 & - & - & - & - \\
\hline $4 \mathrm{a}-\mathrm{CO}_{2} \mathrm{Me}$ & & & 170.3 & & 168.8 & & 168.1 \\
\hline $4 \mathrm{a}-\mathrm{CO}_{2} \mathrm{Me}$ & $3.68(\mathrm{~s})$ & $3.64(\mathrm{~s})$ & 54.0 & $3.63(\mathrm{~s})$ & 53.4 & $3.63(\mathrm{~s})$ & 53.6 \\
\hline $8-\mathrm{OH}$ & 12.15 (brs) & $12.24(\mathrm{brs})$ & & 12.11 (brs) & & - & - \\
\hline 4-OCOMe & & - & - & - & - & & 169.8 \\
\hline 4-OCOMe & $2.05(\mathrm{~s})$ & - & - & - & - & $2.39(\mathrm{~s})$ & 21.9 \\
\hline 8-OCOMe & - & - & - & - & - & & 170.0 \\
\hline 8-OCOMe & - & - & - & - & - & $2.04(\mathrm{~s})$ & 20.8 \\
\hline
\end{tabular}

${ }^{a}$ Recorded in $\mathrm{CD}_{3} \mathrm{CN},{ }^{b}$ Recorded in $\mathrm{CDCl}_{3},{ }^{\mathrm{c}}$ Multiplicity, $J$ in $\mathrm{Hz},{ }^{\mathrm{d}}$ Overlapping signals.

acetonitrile. The active fraction was finally purified on preparative HPLC (column; YMC AM312, 0.6 i.d. $\times 15$ $\mathrm{cm}$, mobile phase; aqueous $50 \%$ acetonitrile, flow rate; $1.0 \mathrm{ml} /$ minute) to yield $\mathrm{F} 390 \mathrm{~B}(1,0.5 \mathrm{mg})$.

The culture broth of Penicillium sp. AJ117291 (2.8 liters) was centrifuged at $4000 \mathrm{rpm}$ for 20 minutes and the resulting supernatant was applied to a column of Diaion HP-20 $(150 \mathrm{ml})$. After washing with water and aqueous $50 \% \mathrm{MeOH}$, the column was eluted with $\mathrm{MeOH}$. The fraction eluted with $\mathrm{MeOH}$ was concentrated in vacuo. The concentrate was then adjusted to $\mathrm{pH} 2.0$ with $5 \% \mathrm{HCl}$ and extracted with EtOAc (150 $\mathrm{ml} \times 2$ ). The organic layer was evaporated to dryness. The residue was subjected to a column of reverse phase silica gel (1.6 i.d. $\times 14 \mathrm{~cm}$ ), and eluted with aqueous $30 \%$ acetonitrile. The active fraction was chromatographed on a Sephadex LH-20 column $(1.6$ i.d. $\times 27 \mathrm{~cm})$ with aqueous $70 \% \mathrm{MeOH}$. Further purification was achieved by preparative TLC (Kieselgel 60 Art 13794 Merck) developed with $n$-hexane-EtOAc-MeOH $(10: 10: 1)$ to give $\mathrm{F} 390 \mathrm{C}(\mathbf{2}, 1.9 \mathrm{mg})$. This fungus also produced F390.

The physico-chemical properties of F390, F390B and F390C are summarized in Table 1 , and ${ }^{1} \mathrm{H}$ and ${ }^{13} \mathrm{C}$ NMR
Fig. 2. ${ }^{1} \mathrm{H}^{-1} \mathrm{H}$ correlation in the COSY spectrum and ${ }^{1} \mathrm{H}-{ }^{13} \mathrm{C}$ correlation in the HMBC sprctrum of 4 .

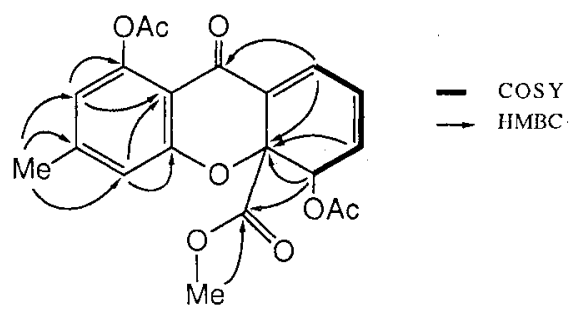

spectral data are in Table 2. They had same adsorption maxima at $340 \mathrm{~nm}$ in the UV spectra, and showed negative Cotton effect at $335 \mathrm{~nm}$ in the CD spectra. The molecular formula of the major component, F390 (3) was determined as $\mathrm{C}_{16} \mathrm{H}_{14} \mathrm{O}_{6}$ by HR FAB-MS and ${ }^{13} \mathrm{C}$ NMR spectrum. Acetylation of $\mathbf{3}$ with acetic anhydride/ pyridine gave the diacetate $(\mathbf{4}, 67 \%$ ) (also see Table 2 for NMR spectra). The structure of $\mathbf{3}$ was elucidated as shown in Fig. 1 by analyses of 2D NMR spectra $\left({ }^{1} \mathrm{H}-{ }^{1} \mathrm{H}\right.$ COSY, HMQC and HMBC) of diacetate (4) to avoid complexity in analyses of the ${ }^{1} \mathrm{H}$ and ${ }^{13} \mathrm{C}$ NMR spectra 
Scheme<smiles>CO[C@]12Oc3cc(C)cc(O)c3C(=O)C1=CCC[C@@H]2O</smiles>

3

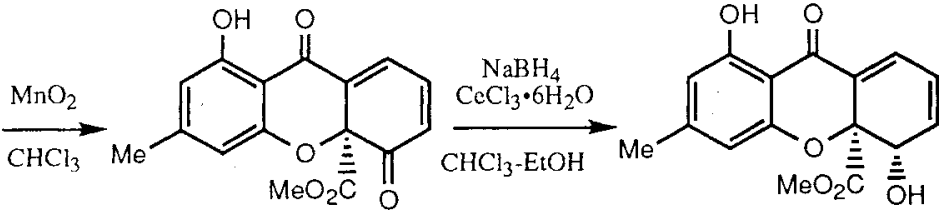

5

6 of 3 due to overlapping the signals. The correlations in the ${ }^{1} \mathrm{H}-{ }^{1} \mathrm{H}$ COSY and HMBC spectra are shown in Fig. 2. F390 was identified as nidulalin A by comparison with an authentic specimen ${ }^{1)}$.

The molecular formula of F390B (1) was deduced as $\mathrm{C}_{18} \mathrm{H}_{16} \mathrm{O}_{7}$ from the HR FAB-MS. The ${ }^{1} \mathrm{H}$ NMR spectrum of F390B was similar to that of nidulalin A. The compound (1) contained an additional methyl group observed at $\delta$ 2.05. The oxymethine proton of 1 was shifted downfield ( $\delta 5.94)$ compared with that of $\mathbf{3}$. These observation indicated that $\mathbf{1}$ was monoacetate of hydroxyl group at C-4 position of nidulalin A (3). This was confirmed by comparing 1 with ${ }^{1} \mathrm{H}$ NMR and CD spectra and by identity with monoacetate prepared from 3.

The molecular formula of F390C (2) was determined by HR FAB-MS and ${ }^{13} \mathrm{C}$ NMR spectrum as $\mathrm{C}_{16} \mathrm{H}_{14} \mathrm{O}_{7}$. The ${ }^{1} \mathrm{H}$ and ${ }^{13} \mathrm{C}$ NMR spectra of $\mathrm{F} 390 \mathrm{C}$ were also similar to those of nidulalin A. The methyl signal on the aromatic ring was not detected and oxymethylene signal $\left(\delta_{\mathbf{H}} 4.57\right.$ and $\delta_{\mathrm{C}} 64.0$ ) was newly observed. These results suggested that the structure of $\mathrm{F} 390 \mathrm{C}$ was the hydroxymethyl analog at C-6 position of nidulalin A. Absolute configuration was deduced from the $\mathrm{CD}$ spectra and the coexistence of both compounds in the same fungus, since they are probably derived from anthraquinone derivative by the same biosynthetic pathway ${ }^{3}$.

To evaluate the cytotoxic activities of related compounds of these xanthones, 3 was oxidized with $\mathrm{MnO}_{2}$ to afford unsaturated ketone $(5,96 \%)$, from which the ketone was reduced with $\mathrm{NaBH}_{4} / \mathrm{CeCl}_{3} \cdot 6 \mathrm{H}_{2} \mathrm{O}$ to give $4 S$ isomer $(6,62 \%)$ (Scheme). The ${ }^{1} \mathrm{H}$ NMR spectrum $\left(300 \mathrm{MHz}\right.$, in acetone- $\left.d_{6}\right)$ of 5 is as follows: $\delta 2.33(3 \mathrm{H}$, s), $3.68(3 \mathrm{H}, \mathrm{s}), 6.42 \sim 6.44(2 \mathrm{H}, \mathrm{m}), 6.54(1 \mathrm{H}, \mathrm{m}), 7.51$ $(1 \mathrm{H}, \mathrm{d}, J=6.3 \mathrm{~Hz}), 7.52(1 \mathrm{H}, \mathrm{d}, J=4.8 \mathrm{~Hz})$. The ${ }^{1} \mathrm{H}$ NMR spectrum $\left(300 \mathrm{MHz}\right.$, in $\left.\mathrm{CDCl}_{3}\right)$ of 6 is as follows: $\delta 2.32$ $(3 \mathrm{H}, \mathrm{s}), 2.91(1 \mathrm{H}, \mathrm{d}, J=5.4 \mathrm{~Hz}), 3.68(3 \mathrm{H}, \mathrm{s}), 5.29(1 \mathrm{H}$, $\mathrm{m}), 6.22 \sim 6.26(2 \mathrm{H}, \mathrm{m}), 6.41(1 \mathrm{H}$, br s $), 6.43(1 \mathrm{H}$, br s$)$, $7.30(1 \mathrm{H}, \mathrm{dd}, J=1.7,5.1 \mathrm{~Hz}), 12.07(1 \mathrm{H}, \mathrm{s})$.

The cytotoxic activities of these dihydroxanthone
Table 3. Cytotoxic activities of dihydroxanthone derivatives in vitro.

\begin{tabular}{cccc}
\hline & \multicolumn{3}{c}{$\mathrm{IC}_{50}(\mu \mathrm{g} / \mathrm{ml})$} \\
\hline $\mathbf{1}$ & 0.086 & 0.06 & $\mathrm{P} 388$ \\
$\mathbf{2}$ & 0.25 & 0.47 & 0.024 \\
$\mathbf{3}$ & 0.042 & 0.096 & 0.22 \\
$\mathbf{4}$ & 0.19 & 0.18 & 0.023 \\
$\mathbf{5}$ & $>20$ & $>20$ & $>20$ \\
$\mathbf{6}$ & 0.6 & 0.26 & 0.46 \\
\hline
\end{tabular}

Cells were treated with each drug for 72 hours. The proliferation was evaluated by MTT assay.

derivatives in vitro are shown in Table 3. Except for $\mathbf{5}$, they exhibited potent cytotoxic activities against both human and murine tumor cell lines in vitro. Furthermore, 3 was also effective against adriamycin-resistant FM3A mouse mammary carcinoma cells (FM3A/ADR) and its parent cells (FM3A/S) with $\mathrm{IC}_{50}$ values of 0.13 and $0.09 \mu \mathrm{g} / \mathrm{ml}$, respectively. Cytotoxic activity of nidulalin $A$ has not been reported ${ }^{2)}$. Further evaluation of the antitumor activities of these dihydroxanthone derivatives is under investigation.

\section{Acknowledgments}

We wish to thank the members of analytical laboratories in Ajinomoto Co., Inc. for their help in measuring NMR and mass spectra.

\section{References}

1) Kawahara, N.; S. Sekita, M. Satake, S. Udagawa \& K. KAWAI: Structure of a new dihydroxanthone derivative, nidulalin $A$, and a new benzophenone derivative, nidulalin B, from Emericella nidulans. Chem. Pharm. Bull. 42: $1720 \sim 1723,1994$

2) Satio, S.; T. Kameyama, R. Nakagawa, T. Yoshimura, R. Fudo \& Y. SaIren.I, (Ajinomoto Co., Inc.): New antibiotics. Jpn. Kokai 73452 ('96), Mar. 19, 1996

3) KACHI, H. \& T. SASSA: Isolation of moniliphenone, a key intermediate in xanthone biosynthesis from Monilinia fructicola. Agric. Biol. Chem. 50: 1669 1671, 1986 